\title{
$J_{A} \neq 1225$
}

(1994), volume 30, pp. 77-82

Printed in Great Britain

\section{LOW INPUT TECHNOLOGY OPTIONS FOR MILLET. BASED CROPPING SYSTEMS IN THE SAHEL}

\author{
By M. C. KLAIJ†, C. RENARD† and K. C. RFDDY \\ †International Crops Research Institute for the Semi-Arid Tropics (ICRISAT) \\ Sahelian Center, BP 12404, Niamey, Niger, and + Institute National de Recherches \\ Agronomiques du Niger (INRAN), BP 425, Niamey, Niger
}

(Accepled 11 Februari 199.3)

\section{SUMMARY}

Pearl millet is a staple cereal cultivated mainly by subsistence farmers on 14 million ha of the West African semi-arid tropics. Increasing pressure un the land has reduced the length of the fallow perioxls, which are necessary to restore soil fertility, resulting in declining yields. To investigate ways of reversing this decline, three systems combining phosphorus fertilizer application, improved varieties of millet and cowpea, and improved agronomic practices were compared with the traditional inillet cowpea intercrop system in a three year experiment. The most protuctive system involved the rutation of fertilized millet and cowpea. Pre-sowing tillage increased hay and fortder yichds in all the improved systems. The application of fertilizer incseased the anount of available phosphorus in the soil. Soil pll declined somewhat in all treatments, although the initially low soil organic matter did not change.

Sislemas de mijo de bajo consumo en el Sahel

\section{RESUMEN}

El mijo perlado es un cereal básico cultivado principalmente para la propia subsistencia de los agricultures en 14 millones de loccláceas en la zona Iropical semiárida del Africa Cocidental. La crecience necesidad de uso de la tierra ha reducido los perícelos de barbecho necesarios para restablecer la fertilidad del suelos, con la consecuente reducción en el rendimiento de los cultivess. A fin de investigar la forma de revertir este prexeso, se compararon tres sistemas con combinaciones de aplicación de fertilizante de lösforo, variedades mejoradas de mijo y caupi, y mejores prácticas agrícolas, en un experimento de tres años de duración con el sistema iradicional de sicmbra simultánea de mijo/caupi. Fl sistema más productivo fue la rotación Je mijo y caupí con uses de tertilizante. La labranza de la tierra previa a la siembra incrementó el rendimiento de paja y furraje en todos los sistcmas mejorados. La aplicación de fertilizante aumentó la cantidad de fósforo disponible en la tierra. Fon todos los tratamientus se observó cierta reducción en el pH del suelo, si bien no hubo cambios en el inicialmente bajo contenido de materia orgánica del suelo.

\section{INTRODUCTION}

Pearl millet (Pennisetum glaucum (L.) R. Br.) is a major staple cereal cultivated on 14 million ha of the poorer suils of the West African semi-arid tropical Sahelian and Sudanian ecological zones, mainly by subsistence farmers. Millet grain is primarily used for human consumption, but the straw and leaves are important for building construction and animal feed. $A$ high proportion of millet fields are 


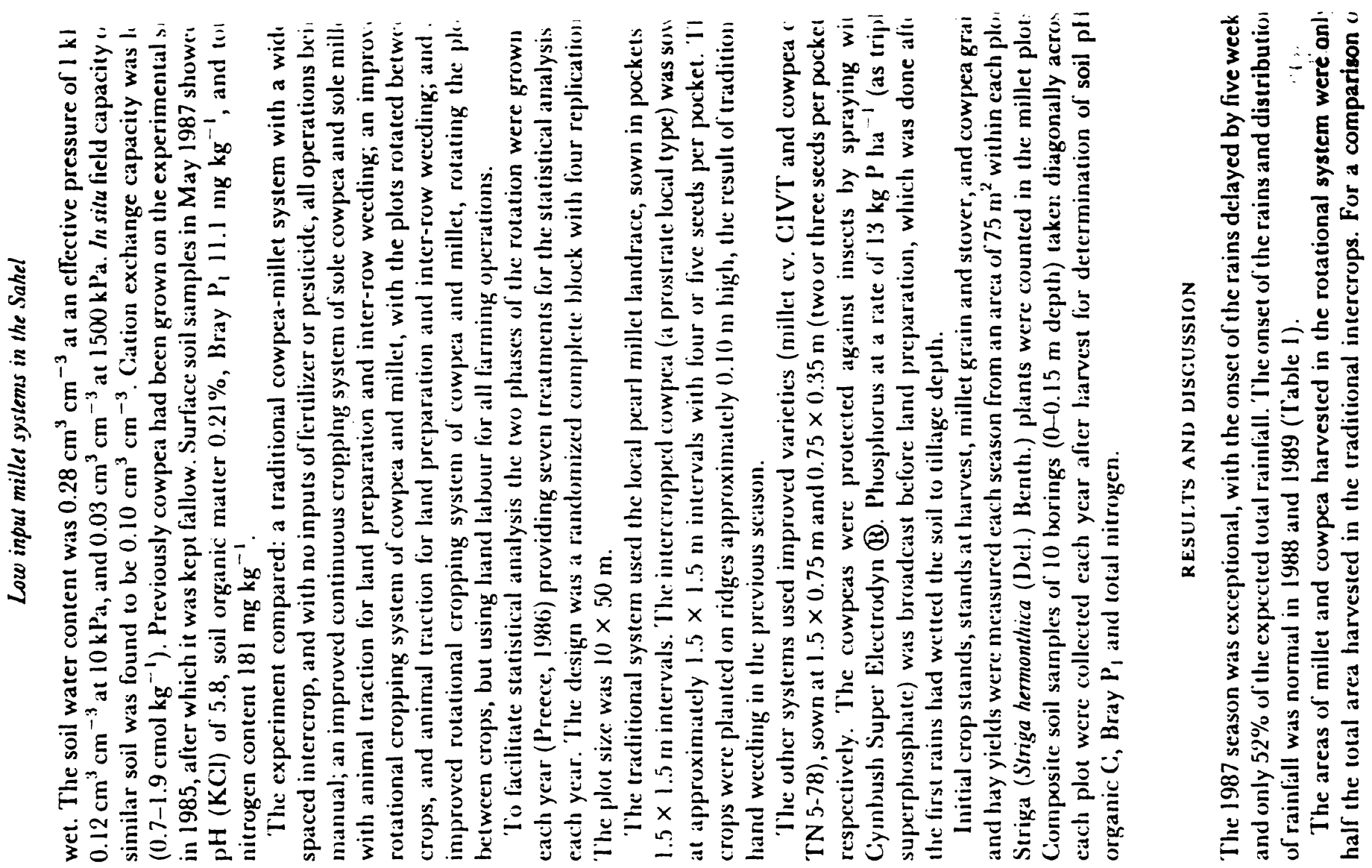

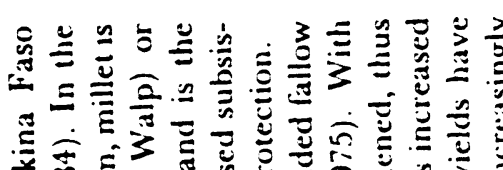

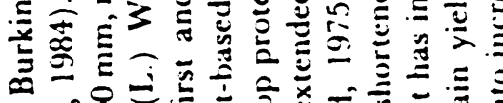

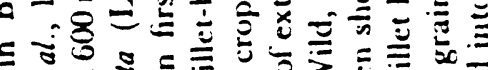

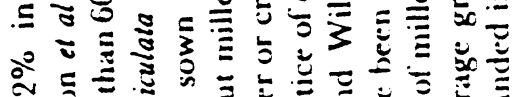
为

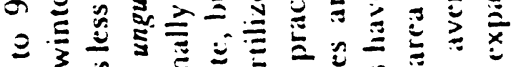

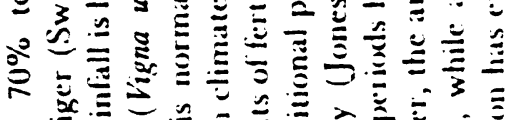

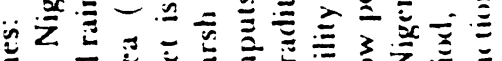
E.

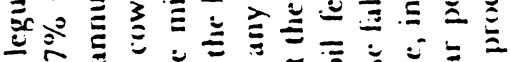

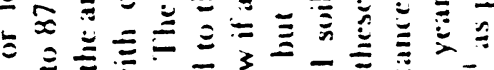

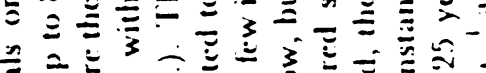

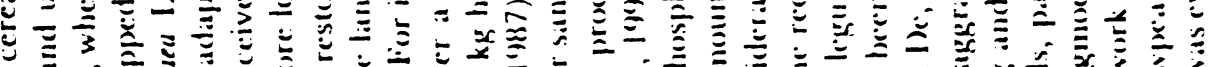

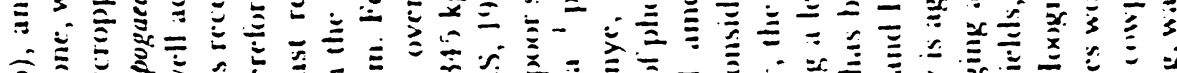

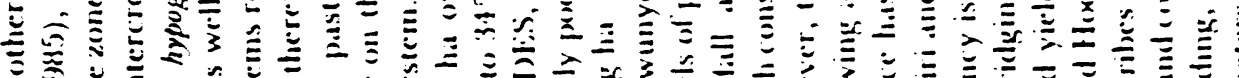

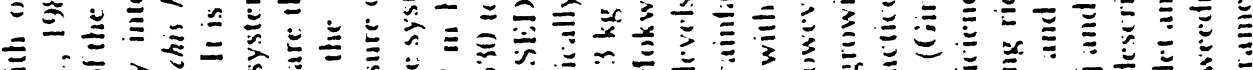

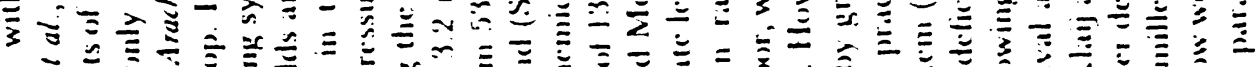

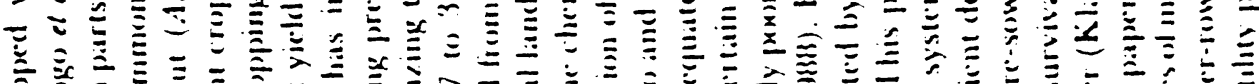

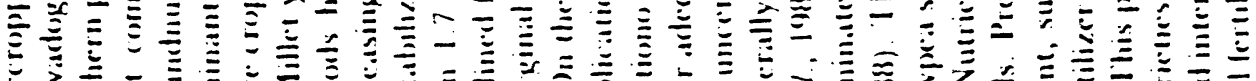

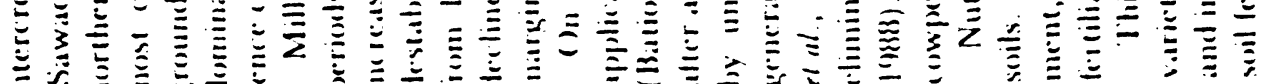

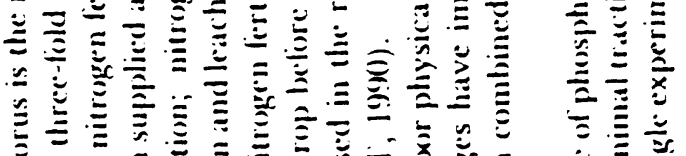

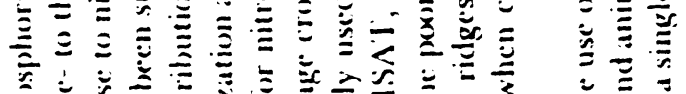

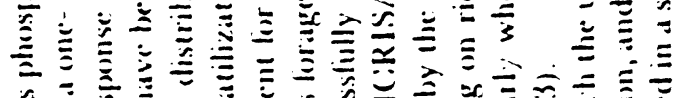

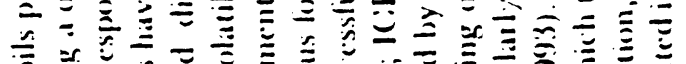

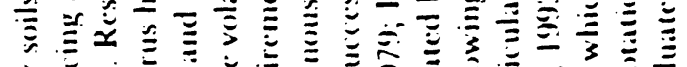

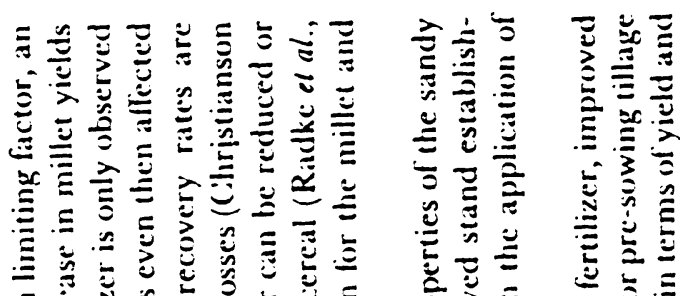

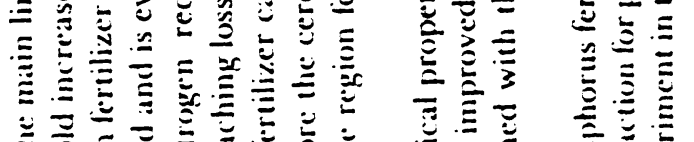
戴

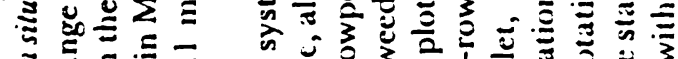

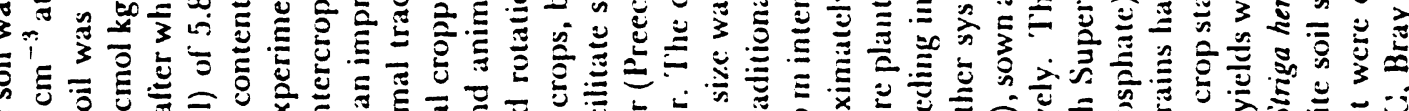

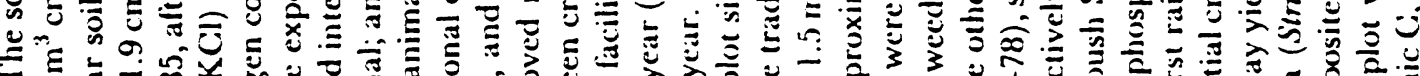

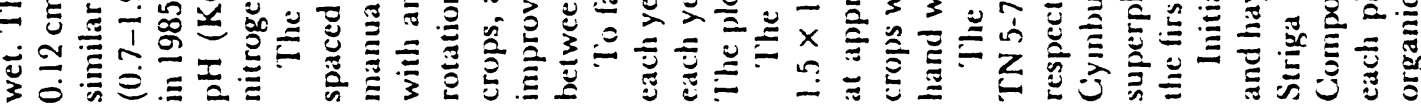

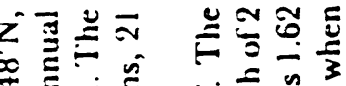

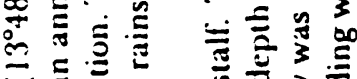

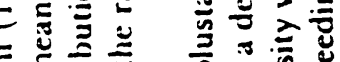

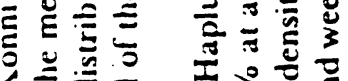

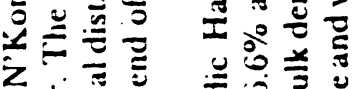

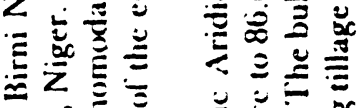$$
\text { כอ }
$$

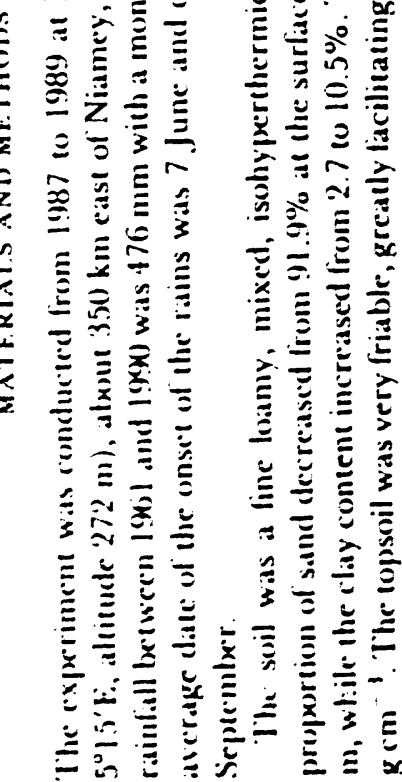



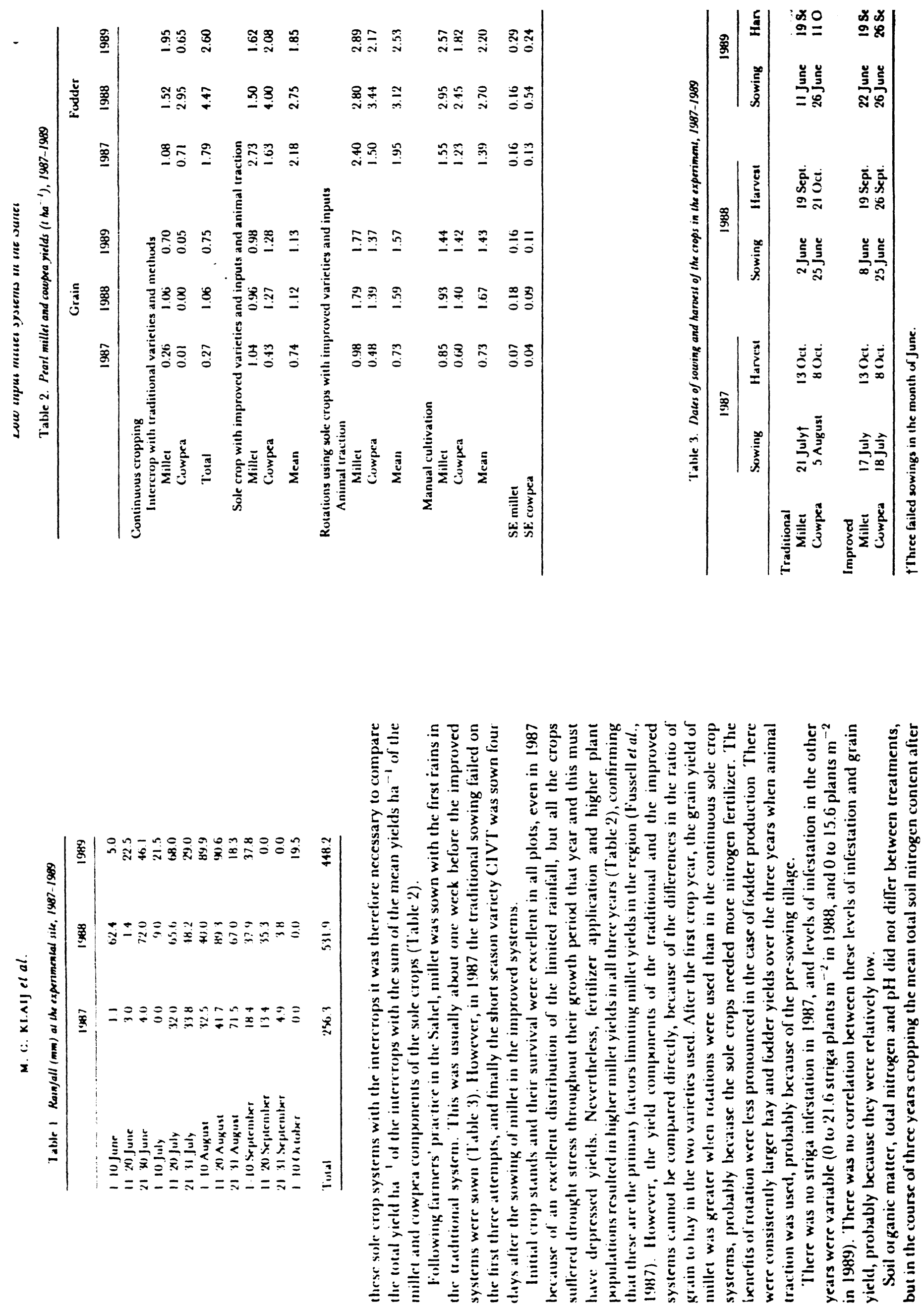
harvest declined from 160 to $125 \mathrm{mg} \mathrm{kg}^{-1}$ of soil, and $\mathrm{pH}$ fell from 5.79 to 5.55 , though no change in organic matter content was observed. Soil phosphorus levels were lower in the traditional treatment, and had fallen $109.0 \mathrm{mg} \mathrm{kg}^{-1}$ by 1989 , though even this level was greater than the $7.9 \mathrm{mg} \mathrm{kg}^{-1}$ considered sufficient for $90 \%$ of maximum altainable millet yield under similar soil and climatic conditions (Bationo and Mokwunye, 1991). It seems likely, however, that continued cropping under the traditional system would ultimately lead to decreased crop yields lecause of phosphorus deficiency. In contrast, the phosphorus level of the improved treatments, to which phosphorus fertilizer was added annually, increased (o) $17.7 \mathrm{mg} \mathrm{Pkg}^{-1}$ by 1989.

Nole. Use of trade names in this paper does not constitute endorsement of or discrimination against any product by the Institute.

\section{REFERENCES}

Hatuono, A Mokwunye, A. II. (1991). Alleviating soil fertility constraints to increased crop production in West Africa. The experience in the Saliel. Fenblizen Research 29:95-115.

(:hristianson, H, Bations, A., Hrnau, A. \& Vlek, P. I. (. (1988). Fale and efficiency of N fertilizers in Niger Plant and Sorl 125.221-231

Fussrll, I. K. Serafinı, P (i., Halusno, A \& Klaij, M. (: (1987). Management practices to increase yield and yichd scability of millet in Alrica. In Procedings of the Inemational Pearl Millet Workshop, 7-ll April

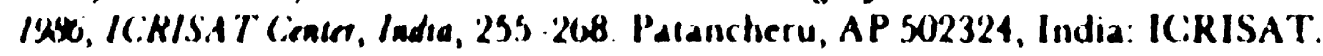

Cin, (: IK, K. (1979). Eillece of preceding grain kgumes un dryland pearl millet in NW India. Expenmencal Agnculeure 15:169-172.

I(:RISAI (InteInaluenal (irops Research Institute for the Semi-Arid Tropics) (1990). ICRISAT West AJucen Propiams Annual Reporl 1989. BP 12404, Niamey, Niger: IC.RISA'T Salielian Center.

Jories, M S. Wilt, A. (1975). Sotls of the West African Sadanna. Commonuralth Burean of Soils, Technical Communkeiton . No. 55. Stough, Farnham Royal, UK. Comnoonwealth Agricultural Burcau.

Klaij, 1 (: Hexgmued, W. H. (19993). Suil management for crop production in the West African Sahel. 11. Himergence, rstablishiment, and yield of pearl millet. Soll and Tillage Research 25:301-315.

Precce, I) A (1966). Sime general principles of crop rotation experiments. Experimental Agriculiure 22.187-198.

Radke, J K. Andrews, R. W., Janke, R. R. Peters, S. F. (1988). Low-input cropping systems and efficiency of water and nitrugen use. In Cropprang Slrakgies for biffriont Use of Waler and Nitrogen. Special PuNviatson S1, 193-218. Madison, W'I: ASA, CSSA and SSSA.

Sawadogo, S., Nagy, J (;. O Ohm, H. W. (1985). Cereal-cowpea associations in Burkina Faso. In Appisponake rachoologies for fiermors is Srme-Arid H'est Africa, 249-259 (Eds H. W. Ohm and J. C. Nagy). IVesi I alayelle, Indiana, USA: Purduc Universily.

SE.DES (Suxseré d'Eludes pour le Développement Fconomique et Social) (1987). Eivde du Sectour Agricole de Viger. Bilen Dingresstir Phase 1. Paris: SH.DES.

Swinion, S. M. Numa, G. Samba, I. A. (1984). Les cultures aseociées en milieu paysan dans deux

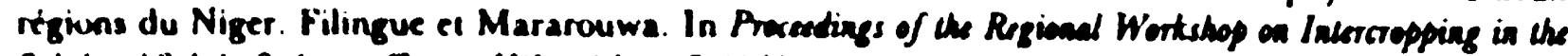

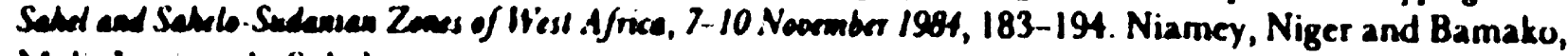
Mali: Instifut du Sahet. 